This is a self-archived version of an original article. This version may differ from the original in pagination and typographic details.

Author(s): Lähdesmäki, Tuuli

Title: Aesthetics of Geometry and the Problem of Representation in Monument Sculpture

Year: 2017

Version:

Copyright: @ Springer International Publishing AG 2017

Rights: In Copyright

Rights url: http://rightsstatements.org/page/lnC/1.0/?language=en

Please cite the original version:

Lähdesmäki, T. (2017). Aesthetics of Geometry and the Problem of Representation in Monument Sculpture. In K. Fenyvesi, \& T. Lähdesmäki (Eds.), Aesthetics of Interdisciplinarity : Art and Mathematics (pp. 275-290). Birkhäuser. https://doi.org/10.1007/978-3-319-57259-8_17 


\title{
Aesthetics of Geometry and the Problem of Representation in Monument Sculpture
}

\section{Tuuli Lähdesmäki}

\begin{abstract}
Since the 1920s and 1930s, constructivist and concretist visual art movements have stressed geometric forms, proportions and orders as a base for artistic expressions and aesthetic experiences. After the World War II geometric form was adopted to the public sculpture. Abstract, geometrically constructed sculpture was also used in commemorative functions in modern monument art. The combination of the commemoration of a significant historical event or a national hero, and the aesthetic ideas based on constructivist or concretist art movements caused a lot of debates and confrontations in many Western countries. In particular, the interpretation of abstract monuments problematized: abstract monuments were often interpreted (or tried to be interpreted) as metonymic or metaphoric depictions or more or less symbolic images of the person or event for whom they were erected. The idea of representation or the symbolic meanings, however, contradict the principles of constructivist and concretist visual art movements. The article discusses two contemporary constructivist and concretist monuments in Finland and illustrates how the problem on representation has been solved in the public reception of them.
\end{abstract}

\section{Representation and reception as a discourse}

Erecting a public monument for the commemoration of a person or an event is an act, which pertains to several areas of social life: art and aesthetics, reminiscence and memory, communality and identity, understanding and narration of history, spatial experience, social norms and politics. The monument projects often cause active public discussions or even severe debates on different meanings and possible interpretations of the monument. The question on representation is particularly controversial regarding modernist monument sculpture, and it has evoked a varying kind of confrontation and dispute. This question became particularly problematic when forms of art based on geometric abstraction were applied to monument sculpture: the idea of representation or the symbolic meanings contradict the principles of constructivist and concretist visual art 
movements. The combination of the commemoration of a significant historical event or a national hero, and the aesthetic ideas based on constructivist or concretist art movements caused a lot of debates and confrontations in many Western countries after the World War II. In particular, the interpretation was problematized in the reception of the abstract monuments.

In this article I will discuss the problematic of representation in the reception of constructivist and concretist monuments, and explore how the geometric abstraction is perceived and conceptualized in the interpretation process of the work of art attached to various cultural and social meanings due to its commemorative function and the tradition related to the practice of erecting monuments. The empirical focus of the article is on two Finnish presidential monument projects that illustrate different aspects of the problematic of representation. The reception of the monuments was profoundly controversial and both projects caused an intense public debate in Finland in the beginning of the 1990s. Despite the polemics, petitions, and negative criticism, the constructivist or concretist monuments of the former Finnish presidents Risto Ryti and Lauri Kristian Relander were unveiled in the capital city of Helsinki in 1994 and 1996.

I will approach the problematic of representation and the aesthetics of geometrical forms from a discursive point of view. The discursive approach to the reception of monuments enables the analysis of the notion of representation and meaning-making processes. Understanding the aesthetics of geometrical forms from the discursive point of view rejects the universalistic explanations of beauty in geometry, and rather emphasises the transforming character and historicity of the principles in aesthetics of geometrical forms. The perception, reception and description of the geometric abstraction are related to various cultural and linguistic practices and conventions. The theoretical background of the article arises from the approaches of social constructionism which emphasize the reality and the 'truth' as constructions produced in language, interaction and social practices (Shotter 1993, 6-10, 99-101; Gergen 1999). In this article I define discourse as a particular way of representing reality (Fairclough 1992, 3-4). These representations, expressed in the reception of geometric abstraction, construct the monuments and the aspects related to them in a complex way. These representations also indicate the power positions and hierarchies intertwined in the use of language and the meaning-making processes. The discursive approach is combined in the article with the use of semiotic concepts. Both points of view share a similar kind of understanding of the interpretive nature of reality and the constructive character of language and concepts in the production of meanings. Therefore semiotic concepts, which explain 
and theorize the formation of meanings, are often used as analytic tools in discourse studies (van Dijk 1995; Wodak \& Meyer 2009; Jaipal-Jamani 2011).

The empirical data of the article consists of various types of texts which were a part of the debates of the two monuments in question. The data related to the Ryti monument project consists of 271 , and the Relander monument project of 72 texts. The empirical material has been collected from libraries and Finnish archives. The largest part of the material is formed by news texts and letters to the editors of local, regional and national newspapers. The speakers in the texts represent several positions such as journalists, art critics, artists, officials, and the so-called lay people, who do not hold a public position in cultural or societal fields.

\section{Aesthetic aims of the art movements in geometric abstraction}

Since the 1920s and 1930s, constructivist and concretist visual art movements have stressed geometric forms, proportions and orders as a base for artistic expressions and aesthetic experiences.

The constructivist art movement has it origins in Russia, where artists were inspired to create works of art that - instead of representative qualities - stressed abstraction composed of structural elements: lines, planes and geometric solids with an aesthetics based on the rhythm, proportions and balance of structures. These artistic ideals originated from the earlier pioneers of abstract art, such as the suprematist paintings of Kazimir Malevitš. In 1920 a group of Russian artists and art theorists - who called themselves the First Working Group of Constructivists - formulated the aims of the movement. They thought that the constructivists should turn away from any experimental activity 'removed from life' and towards 'a real experimentation' and the mastering of the creation of structures in a scientific and disciplined way (Harridon \& Wood 2003, 342). Among the group the three-dimensional constructivist works of art were paralleled to non-representational and nonsymbolic works of engineering. Thus, like industrial products, constructivist works of art were often given a serial number instead of a title. (Hohl 2002, 985-986.) Since the revolution the new social and political circumstances in Soviet Russia influenced artistic creation. Besides the artistic and aesthetics dimension, the constructivists considered art and design as instruments in social and ideological transformation of the society. The constructivists actively participated in public life creating propaganda posters, decorations and urban and architectural plans stressing the political and ideological aims of the Bolshevik government, which in the beginning of the 1920s still supported constructivist aesthetics. 
As a part of the ideological strivings, constructivist principles were also applied to public sculpture and monument art. A well-known example of a constructivist monumental work is Vladimir Tatlin's model for the Monument to the Third International. The model - known from photographs and later reconstructions - was made in 1920 but never executed. The model reveals the utopian nature of Russian constructivism: in Tatlin's visions the monument would have been 400 metres high and included three geometrical building blocks rotating at different speeds. (Hohl 2002, 993; Harrison \& Wood 2003, 336.)

The constructivist ideas in art spread quickly to Western Europe and had an influence on other modern art movements. The constructivist ideas were adapted particularly in Germany and The Netherlands, where artists, architects and designers of the Bauhaus and De Stijl further elaborated the aesthetic principles of geometric abstraction. Geometric abstraction was applied to all kinds of designs by both movements, including monument art. For example Walter Gropius - the leading Bauhaus architect - used a constructivist composition in his monument for the memory of the workers shot during the Kapp Putsch in 1920. The monument, made of concrete, was erected in a Weimar cemetery in 1922.

Like constructivism, concretism - or Art Concrete - stressed geometric abstractions and structural composition of forms. Art Concrete was an heir of the constructivist movement in the West. It was originally formulated and introduced by the Dutch artist and architect Theo van Doesburg in 1930. His Manifesto of Concrete Art (1930), which stemmed from the De Stijl movement, emphasized colour, line and surface, and their geometrical composition as the main elements in art. These were considered as concrete elements which did not refer to any subject outside the work itself or symbolise anything. Thus, concretists saw their art as being rational and pure, that is free from the outside elements. (Strietman 1988; Harrison \& Wood 2003, 282-284; Frampton 1982, 112-113.) According to the concretists, the reception of Art Concrete was also 'pure' and 'direct' - concretist art was not understood as requiring any complex interpretation process, because it was seen as referring to nothing else but itself.

The aesthetic ideas of constructivism and concretism had an influence on post-World War II art movements in Western countries. The continuity of the geometry based aesthetics can be perceived in minimalism, which developed in the USA in the 1960s as a counter reaction to abstract expressionism and its stress on colour, energy, emotions, the process of creation, and subjectivity. 
Again, artists found their artistic inspiration from geometry, structural compositions, surfaces, spatial dimensions, proportions, series, and industrial materials. The aim of the movement was to exclude the pictorial, illusionistic and fictive subjects from the works of art, and instead focus on the mode of expression in which the presence of the reduced work itself was seen as creating the content of the work. For example, Donald Judd, the leading figure in minimalist art, stressed an anti-illusionist attitude in the production of art and demanded that the artists had to make their material and spatial qualities 'literally real' (Harrison \& Wood 2003, 824-828).

The idea of art that does not refer to anything else but itself seems to follow the modernist art movement from the first decades of the $20^{\text {th }}$ century to the postmodernist break in culture at the end of the century. In spite of the postmodernist criticism of modernist art, the principles and ideals of 'pure form' and 'direct reception' still influence the discourses of art. Works of art based on geometric abstraction are still produced, and they are perceived and discussed in terms of discourses related to constructivism, concretism and minimalism.

\section{Debates on form in monument sculpture}

Although, the geometric abstraction was actively elaborated and theorized in Western art during the first half of the 20th century, it had only a slight impact on the renewal of urban design. Most of the constructivist and concretist sculptures remained private and thus hidden from the public eye. (Daval 2002, 1037.) However, after the World War II constructivism and concretism were little by little established as mainstream movements in art. Another mainstream art movement of the time was free abstraction, which is often discussed as informalism or vitalism in Western art history.

In the Western art history, these different discourses of modernism were intensively brought to the fore during the 1950s and 1960s. The diverse discourses produced a juxtaposition of the practices and the notions of art - artists and critics positioned themselves either for or against free or geometric abstraction, informalism or constructivism, or vitalism or concretism (Ojanperä 1998, 113; Lindgren 2001, 139; Lindgren 1996, 158). The discourse, which relied on geometric abstraction, stressed theoretical points of view, rationality, spirit and intelligence as the main dimensions of art. Respectively, the discourse bound to free abstraction emphasized emotion, intuition and emotional and experiential reception. (Lindgren 1996, 158-160; Huusko 2001.) In addition, the discourse of free abstraction highlighted organity on the levels of creative process, 
form and function of art. Following the principles of nature, organic (non-mathematical) growth was seen as eligible in the form of art. The discourse also included principles of materiality in sculpture: a sculpture had to be 'honest' to its material. Organity in the creative process was stressed by art talk and criticism which highlighted the ideals of handiwork in the production of sculptures, the process of sculpturing rather than the final artistic product, and the imprints of artistic work on the surface of the work of art. (Lindgren 1996, 19-23, 157; 2001, 135.) The discourse of geometric abstraction ignored the physical work and unique imprints of artists in the artistic process and instead emphasized the works' universalistic aesthetics and the systematic, serial and technical realization reminiscent of industrial production.

The adaption of the abstract form into the commemorative function of monument sculpture has caused a lot of dispute among the receivers in all the Western countries since the 1950s. Monument debates and dispute on public art became an international phenomenon which started to characterise the Western modernist public art in general (Burstow 1989, 472; Gamboni 1997, 132-133, 155, 170). Although the pre-modernist monument art was often controversial as well, the adaption of abstract form into the monument art aggravated the discussion in a new way. A form, which the receivers could have accepted in the so-called gallery art, did not fulfil the expectations laid on communal and commemorative conventions of the monument genre. In the core of these debates was the question of representation of abstract art. The audience, who was not used to abstraction in art, or at least not in public space, expected the traditional expression and figurative depiction of nationally significant persons and events. The fierce comments in the debates indicated notions of art according to which the fundamental principle in art was to represent something and somehow refer to reality. Therefore, the receivers often interpreted, or tried to interpret, abstract art as a simplified and reduced depiction of some real objects, scenes or phenomena. In the reception of free abstraction this was not necessarily a problem, because the works were often based on organic forms or reduced visualizations of phenomena in reality and nature (Lindgren 2000, 240-242).

Besides the discussions on representation, the expected nationalistic and patriotic nature of monument genre kept the monument projects in the focus of the public interest. Among the receivers, monuments were expected to express a common world view of the commemorating community and an established narration of the nation. On the one hand, breaking the conventions of the form of monuments was interpreted as rupturing the communal and national bases of the commemorative practice and the honouring of national heroes. On the other hand, this was exactly the aim of several modernist artists (Berggren 1999, 564; Lindgren 2000, 230). 
In general, the debates and disputes of the monument art in the 1950s and 1960s in Western countries reflected the post-war transformation of the society. From the 1940s till 1960s, all Western countries witnessed several art, literature and culture debates which encapsulated the juxtapositions caused by the changes in culture and society. These debates often dealt with expressions of national identity, interpretations of the recent past, depictions of religion, and expressions of moral codes. The cultural and social impulse to the debates was above all in the rupture of pre-war patriotic-nationalistic values and in the need to redefine the old value systems (Sevänen 1998, 334). Several modernist writers and artists aimed to deconstruct the practices, myths and imageries of national representations and narrations. In monument art this deconstruction occurred both on the levels of content and of form. The abstraction of monument art was a striking mean to renew the nationalistic and conservative values of monument sculpture (Berggren 1999, 564). However, the debates and disputes on representation weakened the relationship between the ordinary audience and modern public sculpture, and brought the ordinary audience apart from the discourses of abstract art (Burstow 1989, 472; Gamboni 1997, 132-133, 155, 170). The relationship of the ordinary audience to modernist monuments was mainly narrowed to the rejection of them, or general disinterest in the monuments which were considered as poor or difficult to understand (Lähdesmäki 2007).

In spite of the continuous debates, the abstract form became common in the Western countries during the 1960s and 1970s. In Finland the major monuments erected in the 1970s and 1980s obeyed the ideas of free abstraction and the aesthetics of informalism. At the same time the geometric abstraction was used in several public sculptures, which - however - were not dedicated to any commemorative function. Finally, during the 1990s the geometric abstraction was applied to major monument projects as well. The adaption of constructivist and concretist aesthetics to monument art burst out the discussions on representation and reception of 'literal reality'. In different discourses of the reception the problem of representation was solved in different ways.

\section{Interpreting geometric abstraction}

In 1989, the Finnish Prime Minister's Office set up a committee to prepare monument projects for three former Finnish presidents, who were not yet commemorated with a monument in the capital city. The first two of the projects were launched for Presidents Risto Ryti (1889-1956) and Lauri 
Kristian Relander (1883-1942). Both were organized as a public sculpture competition in which all inhabitants of Finland could participate. In addition, eight merited Finnish sculptors were invited to participate in Relander's monument competition. The winner of the competition for Ryti was published in 1991. The winning proposal was made by the sculptor Veikko Myller, whose proposal - titled Years of Responsibility - consisted of a constructivist composition of rectangular beams with the height of six metres. The announcement of the winning proposal caused an intense debate, in which the proposal was disputed in newspapers, radio programs, the city council and government meetings, and in several petitions of political and cultural groups. However, the monument, which followed the original proposal, was unveiled by the sitting President Martti Ahtisaari in 1994 (picture 1). The monument is a composition of two parts in which a rectangular beam, executed in bronze, changes its direction in different angles. The competition for the Relander monument was launched while the Ryti debate was still active. The winner of the competition was published in 1993. Matti Peltokangas's winning proposal, titled From bottom to top, from inside to outside, included four massive cubes, whose surfaces were enlivened by straight tracks which diagonally cut the surfaces of the cubes. The cubes were installed in composition that left a cross-shaped space between them. Like the Ryti monument project, the Peltokangas proposal was actively discussed in the media. Finally, the two-meter high monument made of granite was unveiled by the sitting President in 1996 in Helsinki in the same park the Ryti monument is located (picture 2). Both monuments include the name and the years of birth and death of the commemorated president attached either on the monument itself (Ryti) or on the base of the monument (Relander). 


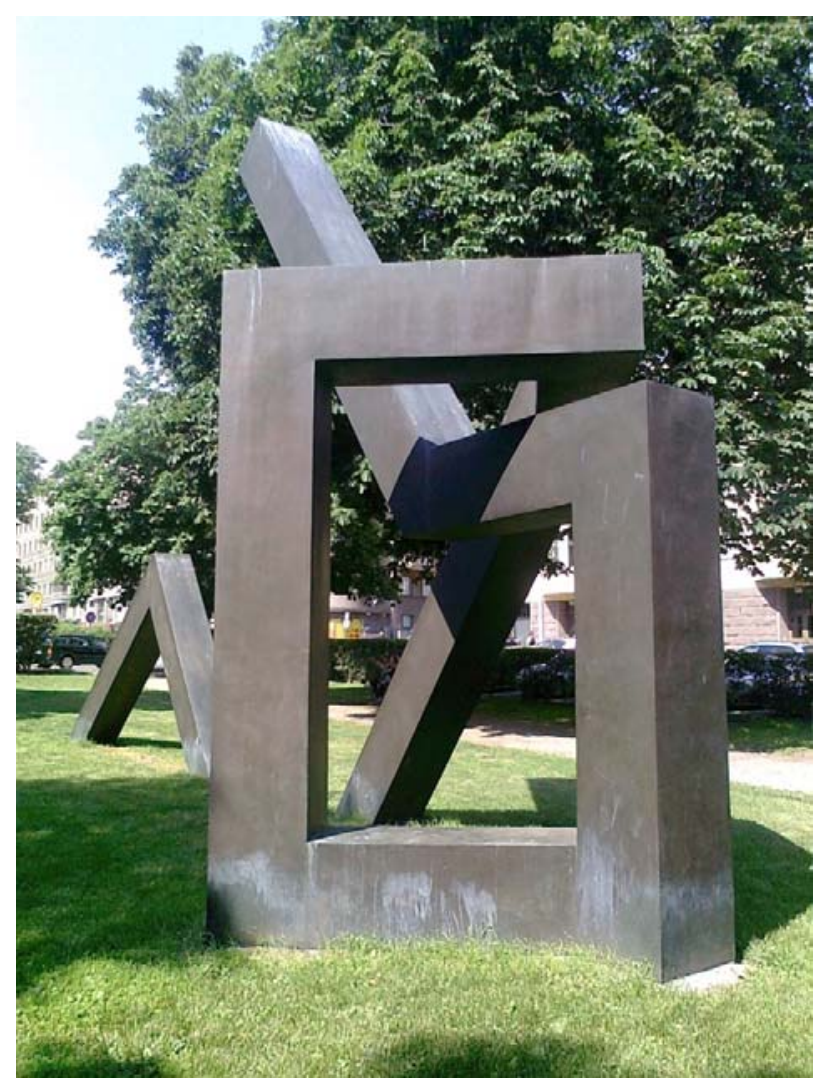

Picture 1. Risto Ryti monument The Years of Responsibility, Veikko Myller, 1994 Helsinki, bronze. Photo: Tuuli Lähdesmäki.

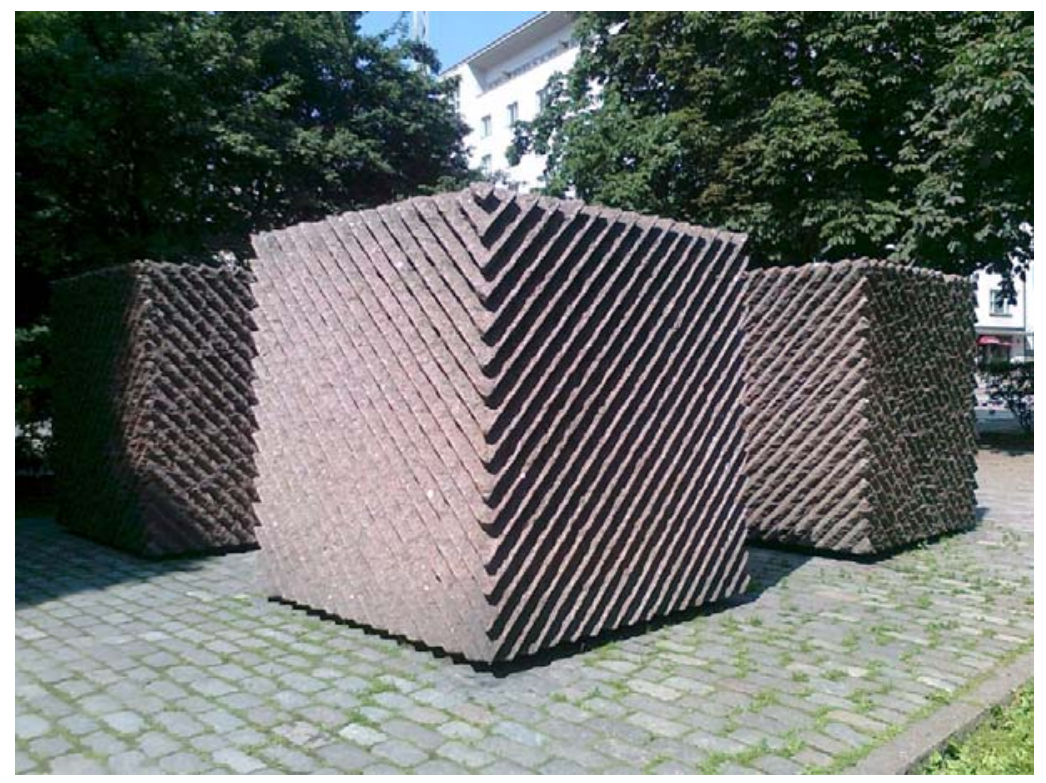


Picture 2. Lauri Kristian Relander Monument From bottom to top, from inside to outside, Matti Peltokangas, 1996 Helsinki, granite. Photo: Tuuli Lähdesmäki.

As the debates on the Ryti and Relander monuments indicate, geometric abstraction causes various challenges to the reception of monument art. Particularly, the combination of commemorative and honoring function of monuments and aesthetic ideas based on constructivism and concretism can be considered as profoundly problematic. Although the ideas of reference, allusion, representation or symbolic meaning contradict the principles of constructivist and concretist aesthetics, the receivers often aspire to solve the problem of representation in the reception of geometric abstraction through them. In different reception discourses the problem of representation is approached and explained in different ways. These ways can be analyzed the help of semiotic concepts: metonym, metaphor and symbol, and seeing them not as features in the work of art, but as features of the reception (Palin 2004, 67; Lähdesmäki 2007, 103). In this sense the reception can be defined as a metonymic interpretation, metaphoric interpretation or symbolic interpretation. Different reception discourses include particular modes of interpretation on both the executed monument and the ideas of an ideal monument; what a proper monument should be like and how a monument should be received (Lähdesmäki 2007, 136-137).

\section{Metonymic interpretation}

The most polemic arguments in the Ryti and Relander debates were expressed by people who wanted the monuments to depict the appearance of the presidents. Because this kind of iconic interpretation was impossible in the case of the Ryti and Relander monuments, those receivers tried to interpret the monuments as figurative representations of some objects in reality. In this discourse the reference to the presidents was produced by interpreting the monuments as metonyms, which offered a concrete link between the geometric form and the commemorated person. According to this discourse, the presidents should have been depicted through representations of objects which would have produced an understandable material link to the president, his deeds or phases of life. These objects were given a function of representing the missing person in the monument. When monuments are received as metonyms, they are expected to function as a kind of a signpost which directs the approach or angle to the commemorated person or event rather than exposing the person or event as such (Ankersmit 1999, 95). 
In the metonymic interpretation the Ryti monument was perceived as representing different constructions related to the World War II. The geometric form of the monument offered various possibilities to link the concrete objects to Ryti, whose presidency in Finland from 1940 to 1944 is tied to the war events and sceneries. The form of the monument was interpreted for example as "bombed railway tracks" (Olin, 1991, Translation TL) or "tank barriers in the fields of Luumäki, which we dug in a rush" (Hyvönen 1991. Translation TL). Respectively, the Relander monument was interpreted representing various objects in reality, as the following quotation from a letter to the editor indicates.

Again the Finnish nation has to marvel at a monument - the statue of Relander. The jury has worked hard and chosen as the first a stack of four stone cubes. Are they dice, which depict the surprising election, of Relander as a black horse? What do the tracks on the surface of the stone depict? Are they imprints on the suitcases of a man, who travelled a lot? (Pseudonym Tarkkailija Pispalasta, 1993. Translation TL.)

In the text, the writer is offering interpretations in which the president is referred through objects which have a connection to him or which can be seen as parts of events related to him. Relander, whose presidency took place from 1925 to 1931, is in Finnish popular history called TravellingLasse, which refers to his way of doing foreign policy by travelling the neighbouring countries much more than his predecessor. Relander was chosen as the president as a so-called black horse due to a game of party politics: his name came up just in the end of the election in the parliament and surprised many.

In the discourse stressing metonymic interpretation of monuments, the proper and the most unambiguous objects through which the monument should refer to the person or event in question are often disputed. Some objects are often seen as natural and unquestionable metonymic signs. The formation of these kinds of 'automatic' metonyms includes the presence of power: some meanings of the persons, their deeds or some areas in history in general are seen more natural or focal than others. 'Clear' or 'unambiguous' metonymic objects are produced in history writing and media through repeating certain depictions and images of persons. Recurrent images and depictions naturalize metonyms.

The metonymic interpretation does not transfer the meanings from one level to another but sees the signs and their referents on the same conceptual plane (Fiske 1990, 96-97). Metonymic 
interpretations operate in the framework of one conceptual level. Therefore, metonyms are less abstract and easier to explain than metaphors or symbols. (Palin 2004, 44.) Due to this feature, the metonymic interpretation was often used in the monument debates to bring to the fore sarcastic or humoristic interpretations. In the causeries and caricatures, monuments were presented as objects whose reference to the presidents produced negative or hilarious connotations.

\section{Metaphoric interpretation}

In the reception discourse, which stressed the artistic expression and creativity in the artistic work, receivers often interpreted the monuments as metaphoric signs. Metaphoric interpretation demands association and seeking similarities between different conceptual levels. Thus, metaphoric interpretation appeals to imagination (Fiske 1990,97-98). Through metaphors it is possible to see some sense and logic in works of art, which would make no sense, were they interpreted literally (Ricoeur 1976, 51). In metaphoric interpretation the representation of the monuments was approached through parallels and analogies. Geometric forms were not seen as representing any objects in reality, but they were perceived as associative expressions. Emotions, atmospheres, features and thoughts associated with the form were perceived as abstractions related to the commemorated person, his deeds and times, and their significance. Metaphoric meanings in the interpretation of monuments were often attached to abstract qualities, values and virtues. In this discourse, abstraction as such was not concerned as a difficult mode of expression, but often even more expressive and revealing than figuration. Paul Ricoeur has discussed the theory of tension connected to metaphors - metaphors are often understood as solving puzzles rather than just an association based on likeness (Ricoeur 1976). This kind of striving to solve 'the puzzle of geometry' characterized the metaphoric interpretation.

In the metaphoric interpretation the abstract form of the Relander monument was interpreted by using an analogy between different conceptual levels. The cubes were interpreted as associative expressions referring to particular emotions, features and ideas characterising the president, his deeds and presidential term. The rising tracks on the cubes and the open structure of the monument were interpreted as metaphors of Relander's interests and actions in opening Finland towards Europe. In an interview in a newspaper, the artist himself explained: "With lines I wanted to depict the periods of economic booms and depressions that the state underwent. In a way, the state opens from inside to outside, and new things from outside get inside" (Kuisma 1993. Translation TL). The 
geometric form and the material of the monument - heavy and hard Finnish granite - were interpreted referring to the actions of the president in stabilising the democracy and constitution in Finland, as the following quotation from an art critic indicates.

I consider the final sculpture composed of four geometric pieces as a modern monument made in the spirit of its subject. Finland's second president Lauri Kristian Relander seems now to be a modern reformist standing out of his time, a reformist, who aimed to open Finland towards Europe. He aimed to stabilise the constitution and democracy. Therefore, strong Finnish granite fits him. (Kivirinta 1996. Translation TL.)

In the Ryti monument, the metaphoric interpretations stressed the reference of the angular form and the dark surface of the monument to the difficult years and decisions during Ryti's presidential term, the horrors of war and his tragic destiny. During the war Ryti signed, in a hard-pressed political situation, a personal contract of alliance with Nazi Germany in 1944. After the war, due to the pressure by the Soviet Union, he was sentenced in Finland to 10 years of imprisonment as being 'responsible for the war'. In the following art criticism, the abstract form is explained in reference to the complex decisions related to the war. In addition, the art critic associates the form of the monument proposal to a falling soldier.

The Years of responsibility is art historically linked to a new wave of constructivism and minimalism of the 1960s. However, Myller's work does not emphasize the autonomy of angular forms, but rather an organic growth from the ground. The artist has planned to cast the final work into bronze, even though the style of the proposal belongs obviously to the tradition of steel sculptures.

The name of the work gives some hints for the interpretation and two quick impressions can be suggested. The movement of the beam represents the complexity of wartime decisions. It generates an association on events, which at times dive into the ground to the realm of Demeter, and rise up again. In addition, a falling soldier can be perceived from the Myller's work, if one takes as a mediator for example Henry Moore's vision on this heroic theme that has its roots in the antique. (Valkonen, 1991. Translation TL.)

As the text indicates, a vitalist discourse of the free abstraction could be applied to the reception of the constructivist monuments. The reference to organic growth intertwines with the vitalist ideas of being 'honest' to the materials and traditions and the conventions related to them. 
Metonymic and metaphoric interpretations are sometimes intertwined in the same texts. However, in both reception discourses a monument is understood as a mnemotechnic sign, whose function is to remind either on particular or more extensive characteristics and narrations related to the person or event in question.

\section{Symbolic interpretation}

In the previous reception discourses, the geometric form of the monuments was interpreted as a reference to certain objects, qualities or events. However, the monuments could also be interpreted as including no representations of the presidents. In this kind of discourse, a monument was understood as a symbolic sign whose reference to the commemorated person was based on cultural agreement - not on the form of representation (see Fiske 1990, 48). Metaphoric and symbolic interpretations differ according to their relation to the reference - metaphors are based on a transposition to another level of meaning or reality, whereas the connection of symbols with its objects is a matter of arbitrary convention, agreement or rule (Fiske 1990, 48, 96-97.) In the symbolic interpretation the monuments were seen as symbolising the presidents and their eras without trying to depict or represent them.

In this discourse, the symbolic function of the monument was based on a convention of dedicating a work of art to a person. Detailed explanations of the representation of form or the symbolic character of the monument were seen as unnecessary or pointless, because they were considered as simplifying the interpretational complexity of a work of art and locking certain interpretations of ambiguous works.

In the discourse characterized by the symbolic interpretation, receivers stressed the reception based in the aesthetic ideas of the constructivist and concretist art. In this kind of reception, the receivers paid attention to the composition of masses, surface structure and its effects, light-shadow variations, and space-mass rhythm in the monuments. Besides the geometric form, the material and its qualities were being taken into account - form and material were considered to be important to fit together. These impressions and features of the form and material were understood as the aesthetic core of the monuments. In addition, the aesthetic experience produced by the form and material was considered as the main meaning of the monuments. Formalistic descriptions were 
recurring particularly in the texts of art critics and in some interviews of the artists. For example, Myller described his Ryti monument as "a two-piece installation, in which he had looked for tension between the parts" (Möttölä 1999. Translation TL). Even though in some interviews Peltokangas had mentioned several metaphoric interpretations of his work, in some other interviews he used a formalistic approach. "I aim to express the movement inside the masses", he described his proposal (Kivirinta 1993. Translation TL).

In the debates, art critics and artists considered monuments first of all as works of art and aesthetic objects, while many of the non-expert receivers stressed the commemorative and honorary function as the main motive for erecting monuments. Views of the art critics and artists reflected their competence and position of expertise in the field of art - phenomena, which were considered as belonging to the field of art, were discussed from the point of view of constructivist, concretist, or vitalist aesthetics.

\section{Conclusions: Social dimension of interpretation}

In Pierre Bourdieu's art sociological theories, art and culture, as well as other social activities, are basically seen as a struggle for symbolic power and 'capital' - the right and the authority to define 'proper' and 'true' meanings and the ability to distinguish 'good' and 'bad' art (Bourdieu 1984; Bourdieu \& Darbel 1991). Bourdieu's sociological field theory and theory about the hierarchies of tastes partly explain the formation of conflicts in the reception of abstract monuments. Monuments can be approached and interpreted through the semiosis of different fields of society, such as art, politics and memory, but the existence of other fields (other than the interpreter's own) is not always recognised or accepted. In Bourdieu's theory the art field forms a hierarchical structure, in which only some tastes and notions of art are appreciated and taken seriously. The struggle over 'good' and 'proper' tastes and notions of art also characterised the monument discussions.

Formalist reception and symbolic interpretation of monuments follow principles, which Bourdieu has characterised as legitimate taste. According to it, works of art are not appreciated because of their representational content but because of their form, which is distinguished from the interest in the subject of the work (Bourdieu1984, 44). This kind of approach is the principle point of departure in ideas of modernist art - form becomes the main content of art, and the mode of expression is merged with the expressed subject. In the monument debates, the art critics and artists 
used both the constructivist, concretist, and vitalist points of view in their comments and articles. These discourses of modernism can be perceived as intertwined and mixed in texts, which combined different modernist perspectives at the same time. The points of view appeared unified particularly when they were juxtaposed with points of view of non-expert receivers. Their critical comments towards abstract monuments in general influenced the texts produced inside the art field - rather than arguing with other art experts, criticism was directed at the arguments of the outsiders. Will to defend the art field, its discourses and its agents against the criticism of the non-expert receivers unified the comments and opinions of the art field. (Lähdesmäki 2007, 255-256.)

As the monument cases of the article indicate, reception and interpretation of geometric abstraction is profoundly complex and includes several discursive and social dimensions. Interpretations of constructivist or concretist monuments are made from different stand points, which reflect the receivers' needs or expectations of representative and illustrative images. In all discussed modes of reception - metonymic, metaphoric and symbolic - interpretations were based on certain traditions or conventions of sculpture. Metonymic interpretations reflected the ideas of traditional figurative sculpture and its ways to represent reality. Metaphoric interpretation leaned on a concept of sculpture in which perceiving the representation requires imagination and a subjective interpretation process - and thus sensitivity for artistic expression. Symbolic interpretation obeyed the aesthetic ideas of constructivism or concretism and followed the modernist discourse, which still partly characterises the discussions of art in the contemporary art field.

\section{Sources}

Ankersmit, Frank B. (1999) "Remembering the holocaust: mourning and melancholia." Anne Ollila (ed.), Historical perspectives on memory, 91-113. Studia Historica 61. Helsinki: The Finnish Historical Society.

Berggren, Lars (1999) “The 'Monumentomania' of the nineteenth century: causes, effects and problems of study.” Wessel Reinik \& Jeroen Stumpeö (eds.), Memory \& oblivion, 561-566. Proceedings of the XXIXth International Congress of the History of Art held in Amsterdam, 1-7 September 1996. Dordrecht: Kluwer Academic Publishers.

Bourdieu, Pierre (1984) Distinction. A social critique of the judgement of taste. London: Routledge. 
Bourdieu, Pierre \& Darbel, Alain (1991) The love of art. European art museums and their public. Cambridge: Polity Press.

Burstow, Robert (1989) "Butler's competition project for a monument the 'The unknown political prisoner'; abstraction and cold war politics.” Art History 12:4, 472-496.

Daval, Jean-Luc (2002) "Monumentality and New Techniques.” Georges Duby \& Jean-Luc Daval (eds.), Sculpture, from antiquity to the present day, 1037-1063. Köln: Taschen.

Fairclough, Norman (1992) “Introduction.”. Norman Fairclough (ed.), Critical language awareness, 1-30. London: Longman.

van Dijk, Teun A. (1995) “Aims of Critical Discourse Analysis.” Japanese Discourse 1, 17-27.

Frampton, Kenneth (1982) "Neoplasticism and Architecture: Formation and Tradition.” Mildred Friedman (ed.), De Stijl: 1917-1931. Visions and Utopia, 99-123. Oxford: Phaidon.

Fiske, John (1990) Introduction to communication studies. London: Routledge.

Gamboni, Dario (1997) The destruction of art. Iconoclasm and vandalism since the French revolution. London: Reaction Books.

Gergen, Kenneth (1999) An Invitation to Social Construction. London: Sage.

Harrison, Charles \& Wood, Paul, eds. (2003) Art in Theory 1900-2000. An Antology of Changing Ideas. Oxford, Blackwell Publishing.

Hohl, Reinhold (2002) "Sculpture Conquers Space.” Georges Duby \& Jean-Luc Daval (eds.), Sculpture, from antiquity to the present day, 998-1017. Köln: Taschen.

Huusko, Timo (2001) "Tahto ja elämä. Uusasiallisuus, persoonallisuus ja vitalismi Lars-Ivar Ringbomin taidekirjoittelussa [Will and life. New Objectivity, personality and vitalism in the art writing of Lars-Ivar Ringbom].” Liisa Lindgren, Hanna-Leena Paloposki \& Elina Heikka (eds.), 
Kirjoituksia taiteesta 3. Modernisteja ja taiteilija-kriitikoita [Writings on art 3. Modernists and artist-critics], 37-46. Helsinki: Finnish National Gallery.

Jaipal-Jamani, Kamini (2011) “A Semiotics Discourse Analysis Framework: Understanding Meaning Making in Science Education Contexts.” Steven C. Hamel (ed.), Semiotics Theory and Applications, 191-208. Hauppauge: Nova Science Publishers.

Lindgren, Liisa (1996) Elävä muoto. Traditio ja modernius 1940- ja 1950-luvun suomalaisessa kuvanveistossa [Living Form. Tradition and modernity in the Finnish sculpture of the 1940s and 1950s]. Helsinki: Finnish National Gallery.

Lindgren, Liisa (2000) Monumentum. Muistomerkkien aatteita ja aikaa [Monumentum. Ideas and times of memorials]. Helsinki: Finnish Literature Society.

Lindgren, Liisa (2001) "Taiteilijuuden metakäsikirjoitus. Raimo Utriainen ja 'tapa tajuta olemassaoloa' [Metascript of being an artist. 'The way of understanding existence' of Raimo Utriainen].” Liisa Lindgren, Hanna-Leena Paloposki \& Elina Heikka (eds.), Kirjoituksia taiteesta 3. Modernisteja ja taiteilija-kriitikoita [Writings on art 3. Modernists and artist-critics], 125-149. Helsinki: Finnish National Gallery.

Lähdesmäki, Tuuli (2007). Kuohahdus Suomen kansan sydämestä. Henkilömonumentti diskursiivisena ilmiönä 1900-luvun lopun Suomessa ["A Surge from the Heart of the Finnish Nation”. Monuments of Great Men as Discursive Phenomena in Finland in the End of the $20^{\text {th }}$ Century]. Jyväskylä: University of Jyväskylä.

Ojanperä, Riitta (2001) "Silmä, liike ja uusi luomiskertomus. Lassi Nummen kuvataidearvostelusta 1960-luvun alussa [Eye, movement and a new Genesis. On art criticism of Lassi Nummi in the beginning of the 1960s].” Liisa Lindgren, Hanna-Leena Paloposki \& Elina Heikka (eds.), Kirjoituksia taiteesta 3. Modernisteja ja taiteilija-kriitikoita [Writings on art 3. Modernists and artist-critics], 135-167. Helsinki: Finnish National Gallery.

Palin, Tutta (2004) Oireileva miljöömuotokuva. Yksityiskohdat sukupuoli- ja säätyhierarkian haastajina [The Symptomatics of the Milieu Portrait. Detail in the Service of the Challenging of Gender and Class Hierarchies]. Helsinki: Taide. 
Ricoeur, Paul (1976) Interpretation theory: discourse and the surplus of meaning. Fort Worth: Texas Christian University Press.

Sevänen, Erkki (1998) Taide instituutiona ja järjestelmänä. Modernin taide-elämän historiallissosiologiset mallit [Art as institution and system. Historical-sociological models of modern art scene]. Helsinki: Finnish Literature Society.

Shotter, John (1993) Conversational Realities. Constructing Life through Language. London: Sage.

Strietman, Elsa (1988) "De Stijl: style and idea." Edward Timms \& Peter Collier (eds.), Visions and Blueprints. Avant-Garde Culture and Radical Politics in Early Twentieth-Century Europe, 270286. Manchester: Manchester University Press.

Wodak, Ruth and Meyer, Michael (2009) “Critical Discourse Analysis: History, Agenda, Theory, and Methodology." Ruth Wodak and Michael Meyer (eds.), Methods of critical discourse analysis, 1-33. London: Sage Publication.

Referred newspapers:

Hyvönen, Heikki (1991)[without title]. Helsingin Sanomat 14 December.

Kivirinta, Marja-Terttu (1993) "Arkaainen ja ajankohtainen, uudenlainen muistomerkki graniitista [Archaic and current, a new kind of memorial in granite]." Helsingin Sanomat 1 June.

Kivirinta, Marja-Terttu (1996) "Koripalloilijan mittaiset kuutiot [Cubes in a scale of a basketball player]." Helsingin Sanomat 30 November.

Kuisma, Kristiina (1993) "Matti Peltokangas voitti Relanderin muistomerkkikilvan [Matti Peltokangas won the memorial competition].” Aamulehti 1 June. 
Möttölä, Marjatta (1999) "Tapio Rautavaaralle tulossa näköispatsas Oulunkylän torille [Figurative statue of Tapio Rautavaa is coming to the market place of Oulunkylä]." Helsingin Sanomat 14 January.

Olin, Kauko (1991) "Räjäytetyt ratakiskot Rytin muistolle! [Exploded railway tracks for the memory of Ryti!]” Helsingin Sanomat 12 December.

Pseudonym Tarkkailija Pispalasta (1993) "Relanderin arpakuutiot [Dices of Relander].” Aamulehti 11 June.

Valkonen, Markku (1991) "Vaikeiden päätösten symboliikkaa [Symbolism of hard decisions]." Helsingin Sanomat 5 November. 